\title{
Transient Mid-Ventricular Ballooning Due to Bad Dream in a Postmenopausal Woman
}

\author{
Puneeth Shridhar', Sina Omran², Raef Hajjali'3 ${ }^{3}$ David Lasorda3 ${ }^{3}$, Ramzi Khalil ${ }^{3}$, Young Jae Chun ${ }^{1,4,5}$ \\ ${ }^{1}$ Department of Bioengineering, University of Pittsburgh, Pittsburgh, USA \\ ${ }^{2}$ Department of Internal Medicine, University of Pittsburgh Medical Center, Pittsburgh, USA \\ ${ }^{3}$ Department of Cardiology, Allegheny General Hospital, Pittsburgh, USA \\ ${ }^{4}$ Department of Industrial Engineering, University of Pittsburgh, Pittsburgh, USA \\ ${ }^{5} \mathrm{McGowan}$ Institute for Regenerative Medicine, Pittsburgh, USA \\ Email: pus8@pitt.edu,yjchun@pitt.edu,dlasorda@wpahs.org
}

How to cite this paper: Shridhar, P., Omran, S., Hajjali, R., Lasorda, D., Khalil, R. and Chun, Y.J. (2016) Transient Mid-Ventricular Ballooning Due to Bad Dream in a Postmenopausal Woman. World Journal ot Cardiovascular Diseases, 6, 329-332. http://dx.doi.org/10.4236/wjcd.2016.610037

Received: August 6, 2016

Accepted: October 7, 2016

Published: October 10, 2016

Copyright $\odot 2016$ by authors and Scientific Research Publishing Inc. This work is licensed under the Creative Commons Attribution International License (CC BY 4.0).

http://creativecommons.org/licenses/by/4.0/

\begin{abstract}
Mid ventricular ballooning syndrome (MBS) was diagnosed in a 55-year-old woman who was admitted to emergency room due to acute chest pain. The trigger for the chest pain was reported as "bad dream" about her husband. MBS, a variant of Takotsubo Cardiomyopathy is more common in postmenopausal women and the triggers have been linked to stress involving the husband. Sudden catecholamine surge during nightmare augmented by estrogen deficiency in postmenopausal women may be the underlying mechanism. There are many unanswered questions related to the etiology of MBS. With supportive treatment, prognosis is excellent.
\end{abstract}

\section{Keywords}

Takotsubo Cardiomyopathy, Mid Ventricular Ballooning Syndrome, Nightmare

\section{Introduction}

Mid ventricular ballooning syndrome (MBS) is an atypical variant of Takotsubo cardiomyopathy (TCM) [1]. The clinical presentation is similar to TCM. It is characterized by transient wall motion abnormalities of the mid-segment of the left ventricle with apical sparing. We report a new trigger to this clinical entity.

\section{Case Report}

A 55-year-old woman presented early in the morning with a past history of hypothyroidism and diabetes mellitus accompanied by her husband to the emergency department after a sudden onset substernal chest pressure radiating to the shoulder blades 
and shortness of breath. An electrocardiogram and cardiac enzymes suggested acute myocardial infarction. Coronary angiography was performed which showed minimal coronary artery disease without a hemodynamically significant stenosis. Left ventriculography was notable for a low normal ejection fraction of $35 \%$, an akinetic anterior and hypokinetic mid-ventricular walls (Figure 1). These findings were consistent with mid-ventricular ballooning syndrome.

The echocardiogram showed abnormality consistent with the left ventriculogram. Upon further investigation the patient admitted to have had a dream involving her husband. The patient was later discharged home on metoprolol, lisinopril and aspirin. One month follow up echocardiogram showed normal LV ejection fraction without regional wall motion abnormalities.

\section{Discussion}

Variants of TCM are generally labelled atypical forms and are seen in $40 \%$ of TCM cases [1]. MBS is one such variant. It is speculated that the difference in density of cardiac adrenoceptors and their susceptibility to sympathetic stimulation in the mid and apical portions might be the reason for variance in ventricular ballooning [2]. It is more common among postmenopausal women [3].

Earlier it was believed that the reason for TCM was coronary artery spasm. However, recent studies have supported increased catecholamine levels during psychosomatic stress are believed to result in development of acute myocardial stunning and LV wall motion abnormalities. Increase in firing rate of unmyelinated cardiac c-fiber afferents produce widespread sympathetic inhibition, thus inducing ventricular ballooning [4]. In addition, estrogen deficiency in postmenopausal women may cause increased sensitivity and responsiveness to catecholamine surges [2]. A sudden emotional stress can induce continued brain activation, which could persist even after the typical cardiac wall motion abnormalities have disappeared [5].

Emotional stress causing TCM in certain group of individuals is highly controversial.



Figure 1. Left angiography showing akinetic anterior and hypokinetic mid-venticular walls confirming midventricular ballooning syndrome. 
Although, some predisposing factors have been identified. Parahuleva et al. have described a case of mid ventricular ballooning without emotional stress [6]. New data has suggested an association between dream anxiety and acute myocardial infarction [7]. Bad dreams have also caused coronary artery dissection and vasospasm [8]. This is the first case report where MBS was caused by a nightmare. In addition, nightmares have been associated with higher sympathetic drive resulting in altered heart rate variability [9]. The stressors in women relating to death or hospital admission of their spouses have resulted in TCM [10]-[12]. It is interesting to note in our case dream relating to husband was the reason for MBS.

TCM is diagnosed more frequent than before. It could be caused by a wide variety of emotional triggers. Further studies are needed to study the detailed mechanism of these triggers which will help us better understand and treat TCM and its variants.

\section{Conclusion}

Mid ventricular ballooning syndrome is a rare condition, but it has excellent prognosis. Sometimes, MBS may have miserable clinical outcome. Our case is interesting since the triggering mechanism, a nightmare, was not reported prior.

\section{References}

[1] Kurowski, V., Kaiser, A., von Hof, K., Killermann, D.P., Mayer, B., Hartmann, F., et al. (2007) Apical and Midventricular Transient Left Ventricular Dysfunction Syndrome (Tako-Tsubo Cardiomyopathy): Frequency, Mechanisms, and Prognosis. Chest, 132, 809-816. http://dx.doi.org/10.1378/chest.07-0608

[2] Balkin, D.M. and Cohen, L.S. (2011) Takotsubo Syndrome. Coronary Artery Disease, 22, 206-214. http://dx.doi.org/10.1097/MCA.0b013e328342532c

[3] Sy, F., Basraon, J., Zheng, H., Singh, M., Richina, J. and Ambrose, J.A. (2013) Frequency of Takotsubo Cardiomyopathy in Postmenopausal Women Presenting with an Acute Coronary Syndrome. American Journal of Cardiology, 112, 479-482.

http://dx.doi.org/10.1016/j.amjcard.2013.04.010

[4] Sverrisdóttir, Y.B., Schultz, T., Omerovic, E. and Elam, M. (2012) Sympathetic Nerve Activity in Stress-Induced Cardiomyopathy. Clinical Autonomic Research, 22, 259-264. http://dx.doi.org/10.1007/s10286-012-0162-x

[5] Suzuki, H., Matsumoto, Y., Kaneta, T., Sugimura, K., Takahashi, J., Fukomoto, Y., et al. (2013) Evidence for Brain Activation in Patients with Takotsubo Cardiomyopathy. Circulation Journal, 78, 256-258.

[6] Parahuleva, M.S., Grebe, M., Neuhof, C., Tillmanns, H. and Erdogan, A. (2013) TakoTsubo Cardiomyopathy in a 92-Year-Old Woman. Clinical Medicine Insights: Case Reports, 4, 13-15.

[7] Selvi, Y., Aydin, A., Gumrukcuoglu, H.A., Gulec, M., Besiroglu, L., Ozdemir, P.G., et al. (2011) Dream Anxiety Is an Emotional Trigger for Acute Myocardial Infarction. Psychosomatics, 52, 544-549. http://dx.doi.org/10.1016/j.psym.2011.04.002

[8] Parmar, M.S. and Luque-Coqui, A.F. (1998) Killer Dreams. Canadian Journal of Cardiology, 14, 1389-1391.

[9] Nielsen, T., Paquette, T., Solomonova, E., Lara-Carrasco, J., Colombo, R. and Lanfranchi, P. 
(2010) Changes in Cardiac Variability after REM Sleep Deprivation in Recurrent Nightmares. Sleep, 33, 113-122.

[10] Surapaneni, P., Vittala, S.S., Vinales, K.L., Najib, M.Q. and CHaliki, H.P. (2011) Atypical Presentation of Takotsubo Cardiomyopathy. European Journal of Echocardiography, 12, 31. http://dx.doi.org/10.1093/ejechocard/jer008

[11] Jongman, J.K., van Tol, C.A., Nienhuis, M.B., Beatrix, S.K. and Elvan, A. (2009) Takotsubo Cardiomyopathy; Reversible Cardiomyopathy Induced by Stress. Nederlands tijdschrift voor Geneeskunde, 153, 363.

[12] Izumi, K., Tada, S. and Yamada, T. (2008) A Case of Takotsubo Cardiomyopathy Complicated by Ventricular Septal Perforation. Circulation Journal, 72, 1540-1543.

http://dx.doi.org/10.1253/circj.CJ-07-0907

\section{Abbreviations}

MBS = Mid Ventricular Ballooning Syndrome,

TCM = Takotsubo Cardiomyopathy,

$\mathrm{LV}=$ Left Ventricle

Submit or recommend next manuscript to SCIRP and we will provide best service for you:

Accepting pre-submission inquiries through Email, Facebook, LinkedIn, Twitter, etc. A wide selection of journals (inclusive of 9 subjects, more than 200 journals)

Providing 24-hour high-quality service

User-friendly online submission system

Fair and swift peer-review system

Efficient typesetting and proofreading procedure

Display of the result of downloads and visits, as well as the number of cited articles Maximum dissemination of your research work

Submit your manuscript at: http://papersubmission.scirp.org/

Or contactwjcd@scirp.org 